\title{
A CONVERSÃO SOCIOPROFISSIONAL DAS ELITES: DOIS CASOS HISTÓRICOS NA HUNGRIA'
}

\section{THE ELITE'S SOCIO-PROFESSIONAL CONVERSION: TWO CASES IN HUNGARY}

Victor Karady*

A "conversão de classe" das elites é uma forma singular de mobilidade social que ocorre quando certos grupos - incapazes de continuar assumindo suas antigas funções ou não tendo mais interesse nelas - optam por novos papeis públicos, seja no domínio econômico propriamente dito ou em outros domínios privilegiados pelos interesses de classe, como o político, o intelectual ou o profissional. Na maioria das vezes, tal "conversão" não atinge todo o grupo, mas apenas suas frações mais motivadas ou mais impelidas a buscar novas posições nos campos de atividade que definem posições de classe. Ela sempre tem o objetivo de melhorar as chances profissionais dos agentes sociais envolvidos ou, pelo menos, de impedir a deterioração absoluta ou relativa de sua situação, em relação a um declínio previsível por novos dados da conjuntura histórica. Portanto, a "conversão de classe" serve direta ou indiretamente à salvação ou à proteção das posições de elite.

No que diz respeito às conjunturas que tornam possível a conversão de classe ou que a impõem, distinguem-se comumente dois casos clássicos de mobilidade social: mobilidade "circular" e mobilidade "estrutural".

A "conversão de classe" se inscreve em um movimento circular quando um segmento dominante substitui outro, desclassificando-o, sem que haja modificação substancial da estrutura global da sociedade. Tal mudança das elites pode vir acompanhada de transformações mais ou menos radicais das regras que regem a realização das fun-

\footnotetext{
* É professor do Central European University (CEU, Budapeste/Hungria), diretor de pesquisa Emérito do Centre National de la Recherche Scientifique (CNRS, Paris/FR) e membro do Centre Européen de Sociologie et de Science Politique (CSE-EHESS, Paris/FR). karadyv@ceu.hu.

1. Texto originalmente publicado na coletânea Les Elites: formation, reconversion, internationalisation. Paris, Stockolm, CSEC-FUKS, 1995. A obra foi organizada por Donald BROADY e Monique SAINT MARTIN. A tradução ficou ao encargo de Patrícia Reuillard e a revisão técnica foi feita por Igor Gastal Grill. Devido ao grande número de referências citadas em nota de rodapé (com títulos em húngaro), os membos do comitê editorial decidiram mantê-las, seguindo a normalização original.
} 
ções de elite, como é caso das revoluções realizadas a partir das ideologias de salvação. Mas pode haver também uma mudança de elite que afete apenas o próprio pessoal do poder (em forma de permuta) e não as condições de seu exercício. Isso acontece nos golpes de Estado, em um regime sociopolítico que, em certa medida é estável, quando há o ingresso nos negócios de uma nova equipe dirigente após eleições perdidas pela equipe anterior, ou ainda quando, após uma guerra religiosa, por exemplo, uma aristocracia dominante de uma determinada confissão substitui outra. Mudanças circulares de elites desse gênero também podem ocorrer progressivamente quando a decadência gradual de um grupo dominante (por exemplo, de grandes famílias aristocráticas da época feudal) prepara a escalada de novas camadas para as mesmas posições.

A mudança das elites é "estrutural" quando essa "conversão" faz parte de uma transformação geral da estrutura social. Tais mudanças ocorrem constantemente nos sistemas socioeconômicos modernos, caracterizados por uma dinâmica de progresso técnico, de crescimento econômico, de modificação das competências do Estado e dos outros poderes públicos. Semelhante “conversão estrutural” se dá igualmente em sociedades que passaram por uma "mudança circular" de tipo revolucionário. Uma vez que a redistribuição dos lugares do poder acarreta, em geral, também a redefınição dos objetivos visados, de novos "projetos de sociedade" e "contratos sociais", que implicam em um prazo mais ou menos longo em transformações propriamente estruturais.

De modo geral, convém distinguir situações que têm "efeitos de coerção" ou de "impulso" à conversão das elites, de conjunturas socioeconômicas que representam novas chances para elas e que exercem, sobretudo, um "efeito de atração”. A coerção é manifesta quando as funções sociais dos grupos envolvidos ficam superadas e/ou quando a base material que elas asseguraram para a existência da classe se rompe ou desmorona. 0 efeito de atração triunfa, em contrapartida, quando surgem novas funções para certos membros de uma elite com oportunidades de êxito superiores à situação anterior.

Por fim, para compreender e apreciar os fatores que constituem as condições sócio-históricas desses processos de conversão de elites, cabe interrogar sobre seus diversos trunfos, os valores investidos em seus modos de vida, seu habitus de classe e suas aspirações coletivas, assim como as estratégias socioprofissionais que empregam ou são capazes de executar para a conservação ou melhoria de suas posições de classe.

Seguindo essas premissas, analisarei, nas páginas seguintes, dois casos históricos de conversão de elites, que tangem a momentos cruciais da história contemporânea da Hungria. Um deles concerne à tentativa de modernização liberal ao final do acordo austro -húngaro; o outro, aos primórdios do regime stalinista animado por uma utopia modernizadora radical, entre outros aspectos.

\section{De uma nobreza proprietária de terras a uma burocracia política: a transformação da gentry no final do século XIX}

A nobreza húngara, e sua homóloga polonesa, uma das maiores na Europa feudal (cerca de 6\% da população), foi uma classe dominante histórica, fortemente estratificada em vários aspectos. À aristocracia latifundiária titulada - subdividida conforme o tamanho das propriedades, que iam dos grandes domínios da Planície e da Transdanúbia aos feudos modestos dos condes e barões transilvanos - se opunha a nobreza 
média, afortunada apenas em parte (bene possessionati). A pequena nobreza, por sua vez, era bastante numerosa e se distribuía em uma escala de situações variadas: pequenos e médios proprietários, indivíduos compartilhando o modo e o nível de vida do campesinato servil ("nobres de tamancos"), indivíduos cedo reconvertidos em magistrados ou em funcionários do Estado ou dos condados, ou ainda em profissionais liberais (homens da lei, médicos). Essa classe, muito heterogênea devido às suas clivagens ideológicas e religiosas - essenciais, já que muitas das possessões aristocráticas remontavam à Contrarreforma - caracterizava-se por um monopólio quase exclusivo da "capacidade política” e de seus direitos específicos ligados - quando era o caso - à propriedade fundiária e aos privilégios atinentes.

A estrutura legislativa feudal é definitivamente desmantelada após as assembleias no Vormärz (denominado "período das reformas”) e as leis revolucionárias de abril de 1848. A nobreza compartilha sua capacidade política com classes cultas plebeias e com a burguesia comerciante e industrial em uma base censitária. Ao mesmo tempo, a servidão é abolida, privando as propriedades fundiárias nobres da mão de obra gratuita com que contavam até então. Essas medidas legislativas levam a nobreza a concorrer abertamente nos campos político e econômico com as novas camadas oriundas do campesinato proprietário, da nova burguesia ascendente de origem essencialmente alógena (sobretudo judeus e alemães, mas também sérvios, gregos, armênios, etc.), do antigo patriciado corporativista e da in- telligentsia de serviço (“honoratiors”). Essa situação competitiva cria ameaças mais ou menos imediatas para o status da classe dominante da nobreza. Sua integridade estatutária, garantida por seus privilégios feudais, se desfaz. Seu monopólio de políticos eleitos e de elegíveis fica desgastado com o aparecimento de numerosos eleitores plebeus. Todavia, é acima de tudo sua base econômica fundiária que se abala com a evolução que começa no Vormärz e se acelera com a independência do país, reinstaurada no Acordo austro-húngaro de 1867, e com a instauração concomitante do modo de produção capitalista. É a ruína econômica de uma fração crescente da nobreza fundiária que produzirá a gentry propriamente dita nas décadas fınais do século. Esse nome genérico, historicamente datado, remete sumariamente aos membros da nobreza que perderam seu patrimônio fundiário e se confrontam com a necessidade de conversão de classe na Hungria. Mesmo que qualquer avaliação seja precária nesse caso, estima-se que, em 1848, havia cerca de trinta mil famílias nobres com propriedades de tamanho médio. Esse número já cai pela metade por volta de 1867 e, no final do século, restam somente cerca de dez mil famílias. Embora a nobreza média forneça apenas uma parcela da gentry, sua ruína precipitada dá a medida do fenômeno como um todo ${ }^{2}$, que é maciço. Além disso, os índices puramente econômicos tendem a minimizar sua gravidade, porque não dão inteiramente conta do grau de endividamento, da diminuição dos lucros, ou da perda de competitividade no mercado agrícola das terras que os nobres outrora possuíam.

2. Para os dados, ver I.T. Berend e G. Ranki, Középeuropa gazdasàgi fejlödése a 19-20 szàzadban (A evolução econômica da Europa Central nos séculos XIX e XX), Budapest, Közgazgassàgi és jogi könyvkiado, 1967, p. 237-238. 
Conhecem-se as principais causas do declínio econômico geral dessa classe de proprietários, que poupou apenas a aristocracia fundiária: uma parte de suas propriedades foi protegida de alienação pela manutenção do status feudal de bens de mão-morta, cuja extensão permitia melhor a passagem à gestão capitalista confiada a quadros especializados ${ }^{3}$. Porém, o restante dos proprietários nobres - mesmo com níveis idênticos de produção e de custos de produção - viu sua renda diminuir devido à baixa dos preços dos cereais (principais produtos da agricultura húngara) nos mercados mundiais, em razão da concorrência maciça do trigo russo e americano. Para enfrentar isso, deveriam ter diversificado a estrutura dos produtos, modernizado o equipamento, se adaptado aos novos mercados e criado atividades complementares ou alternativas (por exemplo, a indústria alimentícia), para o quê a maioria dos proprietários-administradores nobres não tinha nem competência, nem vontade. Outrora, a disponibilidade da mão de obra servil assegurara uma certa rentabilidade à monocultura de cereais, mas seu desaparecimento enfraqueceu fatalmente muitas médias e pequenas propriedades devido a uma competição agrícola crescente com a chegada, ao mercado, de uma burguesia de empresários rurais inclinada a retomar ou arrendar propriedades deficientes. Como tais empresários eram tipicamente recrutados nos meios judeus, compreende-se por que, em 1910, pelo menos 37\% das pro- priedades de mais de 100 holds (cerca de 2/3 hectares) dadas em arrendamento se encontravam nas mãos dos judeus de religião ${ }^{4}$. 0 fortalecimento dessa burguesia agrária acompanhava paradigmaticamente a ruína da nobreza, que não era consequência da burguesia, mas o contrário: esta tinha virtudes e competências que a nobreza não tinha, como a gestão racional (cálculo correto dos custos e dos benefícios), a introdução de inovações quando os mercados assim o exigiam, o ajuste dos gastos aos ganhos e a recusa de endividamento de risco. A causa mais direta da ruína de uma parte da nobreza deve ser buscada em sua incapacidade de modernizar seu comportamento econômico, principalmente seus hábitos de consumo excessivo, ostensivo e frequentemente ostentador - a título de insígnia do status de classe - independentes dos ganhos. Tal situação exercia naturalmente um forte efeito de "impulso" à reconversão de classe.

Simultaneamente, a modernização do Estado, que se acelerou logo após o Acordo de 1867 multiplicando os postos remunerados na função pública e nos mercados econômicos controlados pelas coletividades, também era um forte atrativo. Em primeiro lugar, tratava-se das posições propriamente políticas, ora eletivas (parlamentos, condados, cidades), ora nomeadas pelo governo (juízes de paz, chefes de cantão, chefe de polícia dos condados, etc.). Em seguida, tratava-se dos diversos postos nos ministérios, nas administrações públicas, na polícia, no

3. Estima-se a extensão das propriedades inalienáveis sob o efeito das disposições feudais de bens de mãomorta no final do século XIX em um terço do total das terras aráveis. Cf. capítulo de Làszlo Katus in $M a-$ gyarorszàg története, 1890-1914, (orgs.) F. Mucsi e P. Hanàk), Budapest, Akadémiai, 1978, p. 303.

4. Cf. Magyar statisztikai közlemények, 56, p. 452-457. Na verdade, a proporção da "burguesia rural” de origem judaica devia ser um pouco mais elevada, talvez da ordem de 40\%, considerando a frequência maior dos batismos nesses meios burgueses, mesmo no campo. 
exército nacional reconstruído, na magistratura, etc., nas profissões intelectuais no sistema de educação e nas instituições de saúde assumidas pelo Estado ou nos serviços industriais recém-criados das coletividades públicas (água, gás, eletricidade), nas agências econômicas estatais (minas, florestas e outras propriedades). Por fim, nas empresas semipúblicas ou indiretamente sustentadas pelo Estado - com frequência, cedo ou tarde nacionalizadas - como certas companhias de seguros, bancos e, sobretudo ferrovias e outros transportes públicos urbanos.

Esse movimento de modernização e de expansão dos serviços públicos e parapúblicos também atraiu outros candidatos aos postos, além dos nobres em busca de vagas. Contudo, na conjuntura da virada do século, um conjunto de circunstâncias históricas tornou a clientela nobre praticamente dona desses novos mercados. Podem-se resumir os elementos essenciais dessa problemática em três registros.

Em primeiro lugar, o Acordo que assegurava a independência do país no âmbito da Monarquia Dual comportava, implicitamente, um contrato social que, a despeito da democratização formal e moderada das instituições (democracia parlamentar de sufrágio limitado aos descendentes da nobreza e às outras classes cultas e/ou possuidoras), garantia a hegemonia política da aristocracia e, por meio dela, dos grupos nobiliários e aparentados. De fato, as novas camadas ascendentes, cuja importância crescia nos mercados econômicos capitalistas e no mercado escolar - quase sempre de origem alógena (sobretudo judaica) ou recém-elevadas a classe dominante - ou não dispunham da notoriedade familiar e das relações sociais necessárias ao sucesso político, ou eram impedidas por aqueles que detinham o poder, não podendo pretender a uma influência política proporcional ao seu poder econômico. Deste modo, em 1890, por exemplo, no mínimo 59\% dos funcionários ministeriais pertenciam às famílias nobres $(2,4 \%$ de magnatas titulados) e, em 1910, mais de 49\% (3,5\% detentores de um título aristocrático). $\mathrm{Na}$ verdade, esses dados pontuais apenas minimizam a influência da nobreza na burocracia política do país. Calculando precisamente o tempo de atividade efetiva dos altos funcionários públicos e totalizando até em meses a presença dos membros da nobreza entre os funcionários dos principais ministérios (do interior, do comércio e indústria, da fazenda, da presidência do conselho), entre 1875 e 1918, só a gentry ocupa cerca de $48 \%$ das posições e os magnatas titulares, $28 \%$, ou seja, perto de $77 \%$ cabem à nobreza em termos de orçamento-tempo. Ela também é super-representada no parlamento até quase o final do antigo regime (à exceção do último parlamento fascista), sobretudo nos partidos das maiorias governamentais. Embora faltem censos do período liberal, entre 1921 e 1931 (época dita de "consolidação" do regime contrarrevolucionário autoritário), encontram-se entre os membros das Assembleias nacionais 44\% de nobres (10\% de magnatas titulados) ${ }^{5}$. Fica claro que a nobreza estabelecida no poder político tinha total liberdade para beneficiar seus aliados familiares e sua clientela próxima com as novas posições criadas no aparelho político e burocrático graças à modernização do Estado. 
Um arranjo desses não podia se realizar apenas com o jogo das relações de força entre antigas e novas elites, ainda mais que o aparelho estatal renovado se confrontava com a tarefa histórica - única na Europa - de construir um sistema institucional moderno, “à ocidental”, do Estado-nação, em um país cuja elite dominante era etnicamente minoritária. Para que o regime instalado fosse viável a longo prazo, um acordo devia ser oferecido às nacionalidades; para sua imposição, a elite não podia negligenciar o apoio de aliados nem alienar o aliado potencial mais poderoso, a burguesia alógena (judaica e outras). Por um lado, o "contrato social de assimilação" previa a recepção social generosa da burguesia no seio das classes médias reorganizadas e mais ou menos abertas aos recém-chegados oriundos do judaísmo, de outros grupos alógenos e até mesmo do povo - desde que se magiarizassem culturalmente e assumissem os valores e objetivos nacionalistas da elite política nobre. Por outro lado, esse contrato previa a conservação de uma dualidade dos mercados dessas classes médias: a nobreza e sua clientela imediata (essencialmente cristã) detêm o poder (isto é, um acesso privilegiado) sobre a função pública e sobre os mercados afins, ao passo que os alógenos (essencialmente os judeus) têm toda liberdade para desenvolver e dominar a economia privada. Portanto, foi esse “contrato social de assimilação" não escri- to, mas escrupulosamente respeitado até 1919 e parcialmente além dessa data - que permitiu, acima de tudo, a modernização do Estado iniciada com o Acordo de 1867. Foi essa modernização que possibilitou a reconversão de amplas frações da nobreza em burocracia política e administrativa. As duas partes do contrato - nobreza e novas camadas - garantiam a liberdade de ação de ambos os lados, ou seja, no que tange à nobreza, praticar uma seleção implicitamente clientelista e discriminatória do pessoal dos mercados sob controle estatal.

De fato, somente a realização da outra parte desse contrato - o desenvolvimento da economia privada - forneceu a possibilidade primária da modernização do Estado. A emancipação jurídica dos judeus, encetada pelas assembleias reformistas em 1840, simbolicamente concluída em 1849 e efetiva a partir da lei de 1867, abriu o caminho para a decolagem industrial do país (Gründerzeit) e para a escalada da burguesia e das profissões liberais judaicas que, já na virada do século, representavam a maioria dos principais segmentos das novas classes médias 6 . Em outras palavras, os investimentos (fontes das rendas industriais e comerciais), os impostos pagos, os empregos criados e o crescimento econômico geral assim produzido pela burguesia ascendente (estimado em cerca de 2,5\% per capita de 1867 a 1919, um dos mais altos da Europa) ${ }^{7}$ constituíram a base material

6. De acordo com os dados do recenseamento de 1910, por exemplo, 46\% dos executivos da indústria e dos advogados, 53\% dos executivos do comércio, 49\% dos médicos, 41\% dos veterinários, 44\% dos redatores de jornais, 38\% dos engenheiros liberais, etc., eram de culto israelita, ou seja, uma porcentagem significativamente superior de judeus de origem. Cf. Magyar statisztikai közlemények, 56, p. 436-609, passim e ibid, 64, p. 205.

7. Cf. o capítulo consagrado à economia por Làszlo Katus in Magyarorszàg története, 1890-1918, op. cit., sobretudo p. 394-397. 0 crescimento dos setores "modernos" foi muito maior do que o da agricultura, ou seja, 4.5\% para as minas e as indústrias e 5\% para o comércio e os transportes. $C f$. loc. cit. 
da modernização do Estado e da reconversão da nobreza. Esta, especialmente os membros carentes da aristocracia titulada, aproveitava de maneira mais direta os lucros dessa dinâmica econômica sob a forma de sinecuras nos comitês decisórios dos estabelecimentos industriais ou financeiros, onde podiam trocar seu capital histórico consolidado no prestígio de seu nome por dinheiro líquido.

É esse mesmo capital social consolidado que fornece, fundamentalmente, o principal trunfo para a conversão. No plano local do cantão, da circunscrição eleitoral ou do condado, as famílias nobres usufruíam diretamente da influência de seu nome para conseguir postos eletivos ou para dar a seus descendentes acesso aos postos da função pública. Seu capital de relações sociais parentesco por aliança, círculos de amigos nas famílias dos "Senhores" (Urak), camaradagem de escola ou de exército (no corpo de oficiais), de colegas de clube, etc. - servia de complemento natural à autoridade e ao prestígio assentados no nome. Eles também dispunham do nível de educação necessário à ocupação dos cargos estatais. A legislação fará disso um critério formal por meio do estabelecimento de um complexo sistema de correspondência entre níveis escolares certificados, postos a serem preenchidos e tabelas de remuneração. Nesse sistema, a certificação das competências presumidas tem uma importância decisiva. Ainda que as posições menores nas administrações locais (cidade, cantão, condado) permanecessem acessíveis com quatro ou seis habilitações do ensino secundário clássico (gymnasium com latim), o exame de conclusão do ensino médio representava - com os estudos jurídicos - a porta de entrada para os escalões superiores da hierarquia do Estado, desde que figurasse entre os outros atributos da classe dos "Senhores" (direito de portar espada, possibilidade de duelo, candidatura de ofício ao posto de oficial no exército). No campo escolar, observam-se dois movimentos maiores que sustentam as estratégias de reconversão da nobreza e de suas clientelas. Em primeiro lugar, o Estado desenvolve quase desmesuradamente a rede do ensino secundário que interessa a esses públicos, a ponto de a Hungria contar, no final do século, com uma densidade de estabelecimentos superior à da França, e com proporções igualmente superiores de indivíduos escolarizados, por unidade de população ${ }^{8}$. Em segundo lugar, o público não judeu opta principalmente pelos liceus clássicos, com latim - via real por excelência "nobre" para os estudos superiores - enquanto os judeus são muito mais

8. Assim, desde 1870, há 178 liceus clássicos e modernos, entre os quais 80 em pleno exercício, que sancionam estudos secundários (Cf. Magyar statisztikai évkönyv, 1873, Anuário estatístico da Hungria, 183), p. 606, ao passo que, em 1876, na França - com uma população duas vezes maior - existem 81 liceus e 251 escolas municipais de primeiro ciclo secundário (142 em pleno exercício), cf. Annuaire statistique de la France. Résumé rétrospectif, 1866, p. 139. A densidade escolar do território era, portanto, quase idêntica nos dois países (com uma leve vantagem para a França) desde essa época do início da modernização escolar. Só que esta se mostra muito mais dinâmica na Hungria, pelo menos quanto aos estabelecimentos para meninos, cujo número só sobe para 343 até 1913 na França (cf. Magyar statisztikai évkönyv, 1911, p. 389). Nessa época, em ambos os países, quase todos esses estabelecimentos dispõem agora de segundo ciclo secundário. No que diz respeito ao número de estabelecimentos de ensino secundário de meninos em relação à população, a Hungria parece ter tido um nítido avanço sobre a França na véspera da Grande Guerra. 
pragmáticos, senão "utilitários" em suas estratégias escolares, investindo acima de tudo (principalmente na primeira fase de sua ascensão social coletiva, no período liberal) na rede dos secundários modernos (Realschulen), nas escolas superiores (Bürgerschulen) e nos secundários comerciais ${ }^{9}$, que permitem apenas carreiras de técnicos superiores (engenheiros) ou funcionários do setor privado.

Convém lembrar, à guisa de conclusão provisória, os resultados socioeconômicos diretos e alguns efeitos indiretos da conversão da gentry à burocracia estatal.

Mencionamos anteriormente o enfraquecimento numérico da nobreza fundiária, cujo processo se acelerou com a integração de uma fração crescente dessa classe às funções públicas. Essa evolução contribuiu, por um lado, para reforçar as posições da aristocracia latifundiária, permitindo evitar ou frustrar (até o fim do antigo regime) qualquer projeto de reforma agrária a favor do campesinato sem terras; por outro lado, contribuiu para consolidar a burguesia rural arrendatária ou proprietária de terras. A passagem da gentry para a política facilitou ainda mais a consolidação de uma estrutura arcaica da propriedade, porque a nobreza política fez tudo para preservar os interesses de seus aliados naturais, principalmente do que ainda restava de nobreza fundiária.
É evidente que a conversão da nobreza marcou profundamente as novas classes médias, as quais, ao invés de aderirem aos valores modernizantes, produtivistas ou racionalizadores do capitalismo triunfante, como nos países ocidentais, adotaram o ponto de vista de uma classe em declínio e na defensiva. A "gentrificação" dessas classes médias no âmbito do consenso liberalnacionalista anterior a 1919 não somente produziu, desde o início, uma certa nostalgia pelo modo de vida dos senhores de outrora e pela manutenção culta - frequentemente de forma caricatural - de muitos de seus elementos, como também um estilo particularmente "senhorial" do exercício das funções políticas e administrativas. Os pequenos chefes oriundos da nobreza continuaram tratando os membros das classes populares, até mesmo da pequena burguesia, como súditos e não como cidadãos livres e com direitos iguais. A magistratura, povoada pelos descendentes da gentry, agia de tal modo que a igualdade perante a lei permaneceu com frequência uma ficção, senão um simulacro, quando se tratava de defender os interesses dos membros de sua classe contra o comum dos mortais. Já o Estado tudo fez para reforçar esse jogo da "gentrificação" de sua burocracia, concedendo de ofício, a partir de certos escalões, qualifıcações nobiliárias aos membros da

9. Para avaliar a eficácia e a extensão diferencial - conforme os meios sociais - das estratégias escolares, lembremos que, em 1867, os judeus ocupam apenas 8,7\% das vagas nos gymnasia, mas 21\% das vagas nas Bürgerschulen. Proporções comparáveis se estabelecerão em 12,5\% e em 40\% respectivamente vinte anos depois. Cálculos feitos de acordo com Lajos Lang, Középoktatàs hazànkban, 1867-1886 (0 ensino secundário em nosso país, 1867-1886), Budapest, 1887, p. 36 (quadro IV). Em 1910, por exemplo, os judeus ocupam 19\% das vagas de alunos nos liceus clássicos (o que constitui, em si, uma sobre-representação considerável, três vezes maior do que a proporção dos judeus na população), contra 36\% nas Realschulen, 26\% nas Bürgerschulen e não menos de 49\% nas escolas de primeiro ciclo secundário comercial). Cf. Magyar statisztikai évkönyv,, 1910, passim. 
alta função pública. A "gentrificação" não somente produziu no entre-guerras, após a eliminação do regime liberal-nacionalista e o impulso contrarrevolucionário, esta "sociedade neobarroca", com seus rituais arcaicos e seus valores reacionários, denunciada anteriormente por um de seus principais precursores ${ }^{10}$, mas também criou uma estrutura social rígida, onde dominantes e dominados - os "Senhores" e o povo e proletários - ficaram separados por uma linha divisória intransponível.

A gentry reconvertida e suas clientelas reestruturaram de fato as classes médias em um novo sistema hierárquico, cujos critérios de posição diziam mais respeito ao nome e ao status (nobre ou plebeu) e ao comportamento (modos da gentry, em particular) do que a critérios modernos de pertencimento a essas classes: cultura social, nível de educação, desempenho e competência profissionais. Em seus esforços de conservação de sua distinção de classe - e também um projeto de realimentá-la - as classes médias gentrificadas e ligadas ao Estado erigiram, primeiramente, barreiras educativas e sociais para o acesso dos marginais, quer fossem alógenos étnicos, pessoas do povo em mobilidade ascendente ou judeus. Em um primeiro momento, grosso modo durante o período liberal que termina em 1918, essas barreiras podiam ser transpostas por quase todos, desde que os recém-chegados tivessem satisfeito os critérios de integração, tais como magiarização cultural, nível educativo elevado (e frequentemente mais elevado - à guisa de compensação - do que o exigido aos filhos de "boas famílias"), adesão aos valores nacionalistas e reconhe- cimento da superioridade da gentry como modelo social das classes superiores. Em um segundo momento, no entre-guerras, as condições de integração passam a ser mais severas e, embora os alógenos continuassem a ser admitidos, os judeus foram excluídos de ofício. Foi assim que, na atmosfera antissemita do entre-guerras, as classes médias gentrifıcadas assumiram o qualifıcativo de “cristãs”. Esses movimentos se acompanharam, evidentemente, de uma tendência geral ao conservadorismo ou ao antimodernismo da mentalidade dominante nessas classes.

Por fim, a "gentrificação" das classes médias ligadas ao Estado, de um lado, e a manutenção da dualidade dos mercados, de outro, têm consequências mais insidiosas a longo prazo no funcionamento distinto dos mercados livres e dos mercados estatais "protegidos" (ou reservados à clientela de tipo gentry) e, mais concretamente, nas condições de competição que neles prevalecem. Em suma, enquanto os mercados livres valorizam essencialmente a competência e o desempenho, os mercados "protegidos" privilegiam o nascimento e o conformismo, chegando a tolerar, senão "proteger", a mediocridade em termos de competência ou de desempenho. Quando os dois mercados são opostos tão cruamente, oposição que terá múltiplas consequências na formação e na estrutura interna das elites húngaras, não se trata de uma hipótese teórica, mas de fatos banais de funcionamento desses mercados. Até o final do antigo regime, a jornada de trabalho diário média é de seis horas na função pública contra mais de oito horas (ou seja, com frequência nove/dez horas) no privado.

10. Cf. Gyula Szekfü, A hàrom nemzedék s ami utàna következik (Três gerações e o que vem depois), Budapest, 1934. 
0 público exige a certifıcação escolar para a alocação de seus postos, ao passo que o privado valoriza mais as virtudes do desempenho (envolvimento com o trabalho, eficácia, competência). 0 público oferece a segurança e a aposentadoria; no privado, elas dependem da competitividade e das negociações coletivas ou acertos individuais. Nessas condições, não é surpreendente que sempre que se comparam empiricamente aqueles que se destinam ao público e ao privado, percebese uma diferença nos níveis de desempenho. Observa-se melhor essa oposição no contraste entre judeus e não judeus - dois casos paradigmáticos -, ainda que a dualidade dos mercados não seja inteiramente redutível à separação dos dois - principalmente no sistema escolar, que oferece um exemplo raro de campos de competição virtualmente livre entre os membros dos dois segmentos ${ }^{11}$. Em uma primeira variante da "mentalidade de tipo gentry”, vê-se de fato um certo desprezo pelo desempenho, até pelo trabalho, pela racionalidade econômica, pela competência, como sendo "coisas judaicas" ou, na melhor das hipóteses, "boas para os alemães". $\mathrm{Na}$ segunda variante (surgida tardiamente, no entre-guerras), brota a ideia de que convém "fazer como os judeus" nesses domínios.

Existe uma relação bastante direta entre a gentrifıcação das classes médias "cristãs" e a crise de antissemitismo quase permanente que se desenvolve graças à escalada do fascismo no período pós-revolucionário (com altos e baixos: "altos" em 1919-1920 e a partir de 1932, e "baixos" durante o governo de "consolidação" do conde Bethlen, entre 1921 e 1931). Com efeito, por intermédio das estratégias de "defesa do corpo" desenvolvidas pelas classes médias "cristãs", principalmente em razão da diminuição dramática dos mercados estatais devido ao desmembramento do país em 1919, instaura-se todo um modelo de pensamento para justificar a "mudança da guarda", isto é, a habilitação exclusiva dos "cristãos” à ocupação de todas as posições de classe média graças à legitimidade histórica dos "magiares puros" (dos quais os judeus não podem fazer parte) - referência mal e mal velada à perenidade da legitimidade histórica da nobreza como elite dirigente. Sabe-se que esse sistema de pensamento levou a admitir, com a legislação antijudaica de 1938-1944, a confıscação mais ou menos pura e simples, primeiro das posições ocupadas pelos judeus nos mercados livres em proveito de seus colegas “cristãos” e, depois, de suas propriedades e outros bens, antes de serem entregues aos nazistas para a "solução final".

\section{Os sobreviventes do Holocausto no apa- relho stalinista: a reconversão de descen- dentes da burguesia judaica (1945-1956)}

A última observação serve de transição apropriada ao estudo do segundo caso de "conversão de elite", observado entre os sobreviventes do genocídio dos judeus da Hungria. Em razão do tamanho dos grupos envolvidos, a amplitude do fenômeno não poderia ser comparada à conversão da gentry, mas suas consequências indiretas não são totalmente distintas, pelo menos no que diz

11. Sobre o diferencial dos desempenhos escolares entre judeus e não judeus, ver V. Karady (com Istvàn Vàri) "Facteurs socio-culturels de la réussite au baccalauréat en Hongrie”, Actes de la Recherche en Sciences Sociales, 70, novembre 1987, p. 79-82; “Juifs et Luthériens dans le système scolaire hongrois”, Actes de la Recherche en Sciences Sociales, 69, septembre 1987, p. 67-96, e sobretudo 68 ss. 
respeito à imagem política dos sistemas em causa. De fato, o antigo regime foi marcado pela presença maciça da gentry em sua administração para dar a impressão de uma sociedade "pós-feudal", ao passo que o regime comunista se caracteriza pela participação de judeus em seu aparelho (sobretudo nos postos mais "visíveis", nos escalões mais altos e em suas agências de repressão), a ponto de alimentar a hipótese, amplamente difundida na opinião pública nos anos 1950, de que se tratava de um "poder judaico" instalado pelo ocupante para se opor ao regime antissemita anterior. Embora constatando o paralelismo invertido dessas representações coletivas (a gentry como figura indígena da continuidade histórica e, no oposto, o judeu como encarnação de uma solução radical de continuidade e o cúmplice do estrangeiro), convém observar a que ponto elas deformam realidades muito mais complexas, ao simplificá-las.

Para começar, os judeus recém-engajados na militância formaram apenas uma fração menor do aparelho comunista, apesar das aparências, e somente uma parte dos sobreviventes do Holocausto optou pelo comunismo na volta dos campos ${ }^{12}$.

De fato, logo após a Segunda Guerra, os comunistas húngaros foram majoritariamente recrutados em quatro fontes principais, independentemente da adesão recente de muitos judeus. Deve-se levar em conta, primeiramente, a importância numérica não negligenciável dos antigos quadros que ficaram na clandestinidade ou que re- tornaram ao país. Isso aconteceu com três ou quatro chefes supremos (os famosos troika ou quadriga do futuro Partido Stalinista, segundo os qualificativos populares da época), cujas relações com suas origens judaicas eram sobretudo negativas, tratando-se de personagens totalmente "assimilados” à causa de Moscou; a maioria dos outros quadros não tinha nada a ver com o judaísmo. A segunda grande fonte de recrutamento foram os outros partidos de esquerda da coalizão governamental entre 1945 e 1948; os quadros foram parcialmente introduzidos pelos comunistas (sobretudo o partido camponês e os sociais-democratas) por intermédio de suas "alas esquerdistas”, a tal ponto que uma parcela desse pessoal não teve dificuldade em se integrar ao aparelho do regime de obediência stalinista desde sua consolidação definitiva em 1948 ("ano da virada”). Em terceiro lugar, o poder comunista, obedecendo à sua ideologia “democrática” própria (que não devia jamais funcionar senão como profecia autorrealizadora), operava uma seleção nas próprias fileiras das classes trabalhadoras para "elevar" os candidatos mais merecedores aos postos vagos. Esses operários e camponeses - chamados de "quadros populares" "saídos das fileiras" - eram os verdadeiros miraculados do sistema. Manifestavam uma adesão resoluta à doutrina salvadora do comunismo porque lhe deviam sua salvação profissional. Por fim, em quarto lugar, o novo regime podia contar com ou-

12. Sobre a diversidade das escolhas ideológicas e identitárias entre os judeus sobreviventes, principalmente sobre o peso do sionismo e da continuidade da orientação assimilacionista tradicional, ver meus trabalhos: Beyond Assimilation, Dilemnas of Jewish identity after 1945, Discussion paper of the Collegium Budapest, Budapest, 1993; “A Shoah, a rendszervàltàs ès a zsido azonossàgtudat vàlsàga Magyarorszàgon”. (A Shoah, a mudança de regime e a crise da identidade judaica na Hungria) in Zsidosàg, identitàs, történelem, Budapest, T-Twins, 1992, p. 23-44. 
tros "reconvertidos voluntários", oriundos da antiga administração ou "persuadidos" a se juntar a ele, quando a oportunidade de explorar, em seu proveito, o capital de prestígio intelectual ou científico que eles detinham justificava a oferta de privilégios especiais em troca da adesão ao menos formal à causa comunista. Esse projeto de "captação de prestígio" recaía sobre escritores de renome e cientistas conhecidos internacionalmente e também se dava post mortem. Vivos e mortos se encontravam lado a lado no estranho panteão comunista, destinado a convencer as "massas hesitantes" do fundamento da causa. Obrigados ou levados por seus próprios interesses, muitos ofıciais, universitários, altos funcionários e quadros superiores técnicos do antigo regime se "salvaram" ou "viraram" a serviço do Estado bolchevique, sem falar de seus seguidores mais modestos, mas bem mais numerosos, para os quais a admissão ou a permanência no novo aparelho respondiam mais a uma preocupação de subsistência do que a uma questão de princípio.

Além disso, deve-se também mencionar a adesão dos sobreviventes do Holocausto, que pertenciam, no mais das vezes, à burguesia comerciante, industrial ou financeira, pequena, média ou grande, ou às profissões liberais e intelectuais, que antes não tinham muitos laços com o comunismo. Na opinião geral, essa adesão foi bem mais espetacular porque parecia verdadeiramente "antinatu- ral", já que eram grupos ou descendentes de grupos socioprofissionais condenados à expropriação e à desclassificação pelo regime. Para compreender seu "ingresso no comunismo”, vamos esboçar, primeiramente, um quadro sociológico desse segmento.

0 próprio Holocausto fez uma singular e cruel seleção social, produzindo uma verdadeira translação para cima da estrutura de classe do segmento judeu sobrevivente - do ponto de vista de seu grau de urbanização, nivel de aburguesamento ou qualidade de assimilação ou de modernidade cultural. A razão principal das perdas seletivas se encontra no fato, bem conhecido, de que a maioria das vítimas foi deportada para os campos de morte do interior do país, e apenas uma parte para os de Budapeste. Ora, não somente a capital oferecia mais chances individuais de salvação do que o interior - desde que se dispusesse de aliados ou relações, o que ocorreu na maioria das vezes com os membros das classes médias ou superiores -, mas também os sobreviventes do gueto da capital também pertenciam com mais frequência do que os interioranos aos meios abastados, "modernizados”, até mesmo - devido aos numerosos casamentos mistos e batizados ${ }^{13}$ - desjudaizados. A essa relação geral se acrescenta a probabilidade específica maior de sobrevivência dos militantes de organizações resistentes, quer fossem quadros dos movimentos sionistas, comunistas, sociais-democratas ou outros, forçados à clandestinidade pelo ter-

13. De acordo com o recenseamento de 1941, no mínimo 18\% da população aparentada foi batizada e a taxa de casamentos judaico-cristãos oscilava em torno de 20\% para os noivos judeus que casaram nos últimos anos antes da primeira lei antijudaica de 1938. Em minhas inúmeras pesquisas sobre esse tema, remeto aos seguintes trabalhos: "Vers une théorie des mariages mixtes. Le cas de la nuptialité judéo-chrétienne en Hongrie dans l'ancien régime”, Actes de la Recherche en Sciences Sociales, 57-58, juin 1985, p. 47-68; "La conversion des Juifs à Budapest après 1945”, ibid., 56, mars 1985, p. 58-62; "Patterns of Apostasy among Surviving Jewry in Post-45 Hungary”, History Department Yearbook 1993, Central European University, Budapest, 1994. 
ror nazista. Mesmo que ignoremos a seleção pelo dinheiro, embora não negligenciável já que uma fração da elite social e comunitária (cerca de duas mil pessoas) conseguiu resgatar sua sobrevivência negociando diretamente com a potência de ocupação - ou as perseguições aos "judeus estrangeiros" (que não puderam provar sua cidadania húngara) desde 1941, parece claro que os sobreviventes se situavam, globalmente, mais "acima" em todos os níveis que definem o status de classe e de aculturação, se comparados aos seus companheiros de destino mortos, do ponto de vista do pensamento.

Esse segmento de sobreviventes tinha também outras características bastante singulares em relação aos que não sobreviveram, e também a seu próprio estado anterior ao Holocausto, principalmente no que diz respeito às suas orientações ideológicas prévias e suas aspirações. Tratava-se de uma elite (ao menos potencial) não apenas profundamente frustrada pela privação de suas prerrogativas de classe, mas também de um grupo que o antissemitismo insidioso da sociedade "neobarroca", o fracasso da resistência liberal ao fascismo e sobretudo suas experiências do genocídio e da liberação pelo Exército Vermelho impeliram decisivamente para a esquerda", inclusive, em muitos casos, para a opção comunista propriamente dita. Quanto às frustrações sofridas, compreende-se que tenham sido numerosas e graves. A influência política dessa elite jamais respondeu às suas aspirações e/ou ao seu poder econômico e profissional. 0 numerus clausus universitário e a agitação antijudaica quase constante nas faculdades privaram seus jovens membros, desde 1920, das condições de estudo normais em seus países, obrigando muitos deles (não menos de 50\% no final dos anos 1920, segundo as estimativas ${ }^{14}$ ) à expatriação provisória ou prolongada. A totalidade do grupo teve seus projetos de mobilidade social impedidos durante todo esse período, mas as interdições profissionais contidas nas criminosas leis antijudaicas de 19381944 o reduziram ao estado de pária, por vezes sem os mais elementares direitos humanos (por exemplo, a livre escolha dos parceiros sexuais ou matrimoniais). Mesmo que não evoquemos os sofrimentos e humilhações sofridos durante o Holocausto, os traumas causados pela perda dos entes queridos, etc., tudo isso basta para descrever a frustração dos raros sobreviventes (um pouco mais de um terço dos perseguidos) e o "efeito de impulso" que ela exerceu para levá-los para o comunismo.

Entretanto, o comunismo também exerceu múltiplos tipos de atração sobre os sobreviventes do Holocausto. Acima de tudo, era o regime liberador. Nenhuma das vítimas sobreviventes podia esquecer esse passado recente e a salvação trazida

14. A esse respeito, ver o estudo clássico do estatístico contemporâneo (antissemita militante) Alajos Kovàcs, "Magyarorszàgi zsido hallgatok a hazai és küllföldi föiskolàkon" (Estudantes judeus na Hungria nas universidades nacionais e estrangeiras), Magyar statistikai szemle, 1938, 9, p. 897-902, sobretudo p. 899. Remeto também a meus próprios trabalhos sobre esse tema: "Funktionswandel der österreischen Hochschulen in der Ausbildung der ungarischen Fachintelligenz vor und nach dem Ersten Weltkrieg”, in V. Karady, W. Mitter (hsg.), Bidungswesen und Sozialstruktur in Mitteleuropa, Köln-Wien, Böhlau, 1990, p. 177-207; "Egyetemi antiszemitismus és érvenyesülési kényszerpàlyàk. Magyar-zsido diàksàg a nyugat-europai föiskolàkon a numerus clausus alatt” (Antissemitismo universitário e carreiras forçadas dos estudantes judeus da Hungria no ensino superior no exterior sob o numerus clausus), Levéltàri szemle, 1992, 3, p. 21-40. 
pelo Exército Vermelho, ainda que muitos preferissem dever a liberação a uma outra potência e usufruí-la em outras circunstâncias. Em segundo lugar, o regime realmente ofereceu - embora estabelecendo novas condições, mais severas - uma integração social sem reservas aos judeus, que o antigo regime havia sempre mais ou menos brutalmente recusado, rejeitando as futuras vítimas (sobretudo em suas últimas fases) em uma alteridade radical. Por fim, e talvez principalmente, o comunismo propunha um novo contrato social, acabando assim com todas as discriminações anteriores que entravavam a mobilidade social dos judeus (mesmo que impusesse outras, inéditas até então, que não visavam especificamente os judeus). Nesse contrato - historicamente inaugural - todas as carreiras políticas, militares, administrativas e técnicas do Estado se abriram para os judeus.

Ora, a abertura da função pública tinha uma signifıcação muito maior no regime comunista do que no antigo regime. É verdade que, para os sobreviventes do Holocausto, tratava-se da reparação de uma injustiça histórica, o fim das frustrações seculares em relação às suas chances "normais" de ascensão social. Deste modo, muitos dos brilhantes intelectuais ou universitários judeus que o reinado antissemita condenou ao desemprego ou relegou a empregos subalternos encontraram, de repente, um posto correspondente a seu nível de formação e de vocação, tais como ex-professores do liceu israelita ou especialistas do partido socialdemocrata, que ascenderam a cátedras da faculdade graças à mudança de regime. Era também, e muito mais diretamente para os jovens que voltaram dos campos, uma revanche ao mesmo tempo abstrata - sobre um destino social até então ruim - e concreta, pela possibilidade de combater os ex-perseguidores e seu sistema ideológico graças ao exercício da violência legítima em nome do Estado stalinista. Era a primeiríssima vez que os judeus podiam responder com as armas das instituições estatais, sobretudo com as dos aparelhos de repressão, à violência antissemita mesmo potencial. Enfım, de modo mais geral, o ingresso na função pública assumiu uma importância desmedida no âmbito da organização do Estado stalinista, que expropriou e nacionalizou o setor econômico privado, desenvolveu a burocracia política, administrativa e econômica e deu uma liberdade de ação e um poder incomensuravelmente maiores aos aparelhos do Estado, comparados com o que ocorria no antigo regime. Outrora, o setor privado garantia carreiras equivalentes, às vezes até mesmo superiores às do público, mas agora o Estado era a única fonte de poder econômico e político, portanto, o único senhor da promoção social e profissional, cuja generosidade se deve aproveitar se ela for acessível.

Os judeus sobreviventes dispunham de trunfos quase "naturais" para tirar vantagem disso. Tratava-se, acima de tudo, de trunfos politicos adquiridos por imputação por esses antifascistas manifestos que, em razão de seu destino trágico, não poderiam ser suspeitos de mancomunar com o antigo regime, mas que, ao contrário, podiam se prevalecer de uma presunção de dedicação ao "regime da liberação". A isso se acrescentou, no caso de certos ex-militantes dos movimentos antifascistas (comunistas de diversos calibres, sociais-democratas, sionistas de esquerda), o "capital político" propriamente dito, acumulado durante os anos de oposição e/ou de clandestinidade (ao menos sob a forma de participação em redes ligadas ao poder comunista) - mesmo que certas formas desse capital (o excessivo sionismo, a social-democracia tomada 
ao pé da letra, o comunismo igualitarista e libertário de obediência não bolchevique) pudessem prejudicar seus detentores durante a dominação do sectarismo stalinista. Para poder ser aproveitado, o "passado de esquerda" exigia uma "reconversão política" de seus titulares em forma de submissão cega à "vontade do Partido". Independentemente disso, esse segmento se distinguia por um nível de educação formal e por uma cultura política informal nitidamente superiores à média, mesmo em classes sociais iguais $^{15}$. Portanto, estava apto a satisfazer, sem formação suplementar, à necessidade aguda de pessoal do novo regime (fala-se comumente de "penúria de quadros"), que ocorria devido à destituição dos funcionários considerados "politicamente não confiáveis”, assim como ao brusco inchaço dos aparelhos de repressão, de administração econômica e outros do Estado stalinista.

Esses efeitos de "impulso" e de "atração" constituíram um conjunto de condições objetivamente favoráveis à adesão dos sobreviventes à ideia e às práticas comunistas. Todavia, convém também lembrar os "contratrunfos”, ou seja, os argumentos e dados contra esse engajamento. Fundamentalmente, trata-se do passado "burguês" do grupo, dos envolvimentos ideológicos anteriores a favor da assimilação de tipo nacionalista ou sionista ou ainda do peso das tradições religiosas e do conjunto dos investimentos econômicos, sociais e simbólicos relacionados. Em todos esses registros, cujo estudo detalhado fiz em outro texto ${ }^{16}$, o regime comunista representou uma ameaça aos interesses de certas frações do segmento sobrevivente. A burguesia estabelecida, seja industrial, financeira ou comerciante, estava fadada à expropriação completa (inclusive ao confisco dos bens imobiliários), e até mesmo ao afastamento da nova sociedade enquanto "inimigo de classe". 0 mesmo ocorria com as profissões liberais (advogados, notários, etc.) quando não conseguiam ser "requalificadas" oportunamente como "intelectuais progressistas”. A repressão, frequentemente selvagem, abatia-se desde a consolidação do poder comunista (1949) sobre os sionistas, sobre os liberais de todo tipo (como os membros da Maçonaria) e sobre todos os "anticonformistas” em relação à linha do partido. Quanto à comunidade religiosa, as três orga-

15. Sobre os problemas da sobre-escolarização judaica na Hungria antes e depois do Holocausto, ver meus estudos: "Jewish enrollment patterns in classical secondary education Old Regime and Inter-War Hungary”, Studies in Contemporary Jewry, I, 1984, p. 225-252; “Assimilation and schooling: national and denominational minorities in the universities of Budapest around 1900”, in Gy. Rànki (ed.), Hungary and European Civlization, Bloomington, Indiana University Press, 1989, p. 285-319; "Juifs et Luthériens dans le système scolaire hongrois”, op. cit.; " Jewish over-schooling in Hungary : its sociological dimension”, in V. Karady, W. Mitter, Bildungswesen und Sozialstruktur, op. cit., p. 209-246.

16. Cf. Trabalhos citados na nota 10, assim como alguns de meus outros textos: "Szociologiai kisérlet amagyar zsidosàg helyzetének elemzésére 1945 és 1956 között” (Ensaio de análise sociológica da situação dos judeus húngaros entre 1945 e 1956), in Péter Kende (org.), Zsidosàg az 1945 utàni Magyarorszàgon, Paris, Cahiers Hongrois, 1984, p. 38-185. Uma parte desse estudo foi publicada em inglês por Randolph R. Braham com o título "Some Social Aspects of Jewish Assimilation in Socialist Hungary, 1945-1956", in The Tragedy of Hungarian Jewry, Social Science Monographs, Boulder, New York, 1986, p. 73-132. Nesse contexto, não se pode esquecer o ensaio clássico do grande cientista político Istvàn Bibo, disponível em francês: "La question juive en Hongrie après 1944" in Misère des petits Etats d'Europe de l'Est, Paris, L'Harmattan, 1986, p. 211-392. 
nizações até então autônomas foram unificadas à força já em 1951, e a vida religiosa foi reduzida ao mínimo tolerado, como os outros cultos, já que o regime stalinista pregava um ateísmo oficial.

Essas condições possibilitam uma melhor compreensão das implicações singulares da reconversão à elite comunista de uma parte dos sobreviventes judeus oriunda das antigas classes burguesas.

Essa reconversão se deu, primeiramente, de modo bastante seletivo, com critérios muito contingentes, ao acaso dos percursos individuais, ainda que também se possam identificar alguns critérios objetivos. Evidentemente, tratava-se sobretudo daqueles que dispunham de um "capital político" de boa qualidade (conforme a definição comunista) e dos jovens "sem passado político", mas que podiam ascender diretamente no culto e na dedicação aos ideais da "nova sociedade”. Para muitos deles, órfãos sem apego ao retorno aos campos, que haviam perdido tudo, o "movimento" (comunista) funcionava eficazmente como família substituta. De resto, eram esses jovens que conseguiam camuflar melhor as "origens burguesas”, que se tornaram comprometedoras para uma carreira no aparelho. 0 filho de um grande arrendatário de terras podia facilmente se fazer passar pelo "filho de um pequeno camponês”, uma vez desaparecidos os ascendentes e os registros com indicações sobre o valor dos arrendamentos.

Ocorria uma seleção negativa contra os "burgueses" manifestos, os sionistas ou aqueles suspeitos ou convictos de simpatias "ocidentais" ou "cosmopolitas" - que equivaliam às inclinações democráticas nas representações comunistas. Contudo, isso não significava uma exclusão completa das carreiras comunistas para os culpados visados. Só que a integração no aparelho devia repousar em esforços bem-sucedidos de "compensação" extras, em uma "vigilância ideológica” redobrada dos quadros ou em um excedente de manifestações de boa fé e de convicções. Além disso, tais quadros eram mais expostos às purgas rituais que marcavam regularmente os grandes momentos da agitação artificial que o comunismo mantinha na opinião pública para justificar e impor suas orientações (as “mudanças da linha”). Para esses quadros, o esforço de "levar a esquecer suas origens" se tornou uma estratégia de sobrevivência ainda mais coercitiva porque o regime continuou desenvolvendo todo um jogo político construído sobre a fantasia do complô. Tal jogo consistia em descobrir e denunciar os "inimigos internos" no combate ao "imperialismo" ou aos "criadores de guerra”. Ora, devido à sua educação ocidental, passado de classe, gostos culturais, relações eventuais com parentes estabelecidos no Ocidente ou em Israel (situação muito mais frequente entre os judeus em razão das ricas tradições de emigração forçada próprias a esse grupo), etc., esses quadros reconvertidos corriam mais riscos de sofrer uma caça às bruxas, prática tão familiar dos regimes stalinistas. 0 porquê de um voluntarismo nas manifestações de engajamento comunista provavelmente mais marcante nesse grupo do que nos outros.

A natureza do percurso em termos de mentalidade, de habitus de classe e de espiritualidade, que os descendentes da burguesia judaica reconvertidos ao comunismo tiveram de percorrer, fez com que certamente figurassem entre os recrutas do Partido e, que, em suma, dessem o "maior salto" no espaço social para realizar seu novo engajamento. Em outras palavras, a conversão de classe para o comunismo representa uma ruptura radical com a he- 
rança cultural que ignorou, até então, as figuras da militância brutal solicitada aos membros do aparelho. Por essa razão, os quadros judeus desenvolveram e cultivaram em excesso o espírito dessa ruptura com suas próprias tradições, o que produziu desde comportamentos deliberadamente opostos aos “costumes judeus" até sentimentos de ódio e desprezo sem iguais por eles e por aqueles que ainda os mantinham - tudo isso no âmbito das mesmas atitudes negativas obrigatórias reservadas aos “inimigos de classe" presumidos. Esse problema da obrigação de denegação das próprias raízes e dos apegos socioculturais se apresentou aos quadros judeus de modo ainda mais forte, não somente porque eles provinham de meios "burgueses", mas também porque muitos sobreviventes de suas famílias que optaram pelo sionismo foram vítimas do terror stalinista ou ficaram simplesmente de fora da mística bolchevique, sendo-lhe até mesmo hostis. 0 ingresso no comunismo provavelmente dividiu mais as famílias, os círculos de amigos ou camaradas na Hungria do que em outros lugares, onde as gerações (faixas etárias) continham ainda segmentos com muita diferença nos níveis de educação, graus de assimilação, escalas de aculturação, relações com a tradição judaica (principalmente a prática religiosa), experiências política e histórica e níveis de politização.

Considerando o caráter frequentemente voluntarista e, de certo modo, estratégico desse engajamento, a conversão ao comunismo nesse meio permaneceu, com frequência, um ato ambíguo em vários sentidos. Primeiramente, era uma escolha forçada entre várias, principalmente em relação ao sionismo. Em seguida, continuava condicionada pela realização de promessas utópicas do stalinismo. Quando as deformações e abusos do regime se mostraram evidentes, uma parte desses quadros se voltou resolutamente contra esses ídolos que outrora haviam adorado. Pode-se situar historicamente o momento de desilusão em torno do ano de 1953, início da desestalinização, em que ocorre a clivagem decisiva entre quadros desiludidos e seus companheiros que perseveraram no apoio ao regime. À força de grande sofrimento, os primeiros continuarão sua conversão até a preparação da Revolução de 1956, da qual serão os principais ativistas intelectuais. Esse caminho prosseguirá, graças à frente popular revolucionária realizada em 1956, com ex-quadros judeus desiludidos e outras forças antibolcheviques, assim como nas prisões do regime kadarista. Os mesmos ou as gerações seguintes de filhos de ex-quadros constituirão igualmente, décadas depois, o núcleo duro da nova dissidência anticomunista. Enfım, a ambiguidade se expressa também em outras reviravoltas que o tempo trará, tais como a passagem ao sionismo e à partida para Israel ou a emigração para o Ocidente, sem falar da migração interna, marcada pelo afastamento do político. Enfim, a ambiguidade do engajamento comunista se objetiva no tabu do judaísmo, que o próprio regime impõe a todos, judeus e não judeus. Após 1948, com a ajuda da laicidade oficial, desaparece toda referência ao judaísmo na vida pública húngara, da historiografia, dos jornais, do ensino, etc. 0 tabu é observado nas famílias dos quadros judeus também, onde os jovens ignoram tudo de suas origens, inclusive dos membros da família desaparecidos no Holocausto. Semelhante denegação da judeidade, em razão de seu caráter coercitivo, apenas exacerbou a importância da questão identitária para aqueles mesmos que fingiam ignorá-la. 
RESUMO

0 artigo examina dois casos exemplares de conversão sócio-profissional das elites na Hungria, pontuando tanto as transformações históricas e sociais, quanto às disposições, estratégias e as expectativas dos agentes empenhados em manter ou conquistar posições sociais. No primeiro caso, demonstra-se que, na segunda metade do século XIX, a necessidade de concorrer com outros grupos e o perigo de perder a sua posição privilegiada na sociedade condicionou a tentativa de modernização liberal da nobreza no acordo austro-húngaro. E, no segundo caso, observa-se que, depois da Segunda Guerra Mundial, nos primórdios do regime stalinista impulsionado por uma utopia modernizadora radical e com um elevado nível de educação, foram criadas oportunidades para um grupo social discriminado no passado de se tornar funcionários públicos, inclusive na administração do Estado.

\section{PALAVRAS-CHAVE}

Elites. Reconversão. Estado. Hungria.

\section{ABSTRACT}

This article examines two exemplary cases of socio-professional conversion of Hungary elites, emphasizing historical and social transformations regarding agent's dispositions, strategies and expectations engaging in maintaining or conquering social positions. In the first case I demonstrate that in the second half of $19^{\text {th }}$ century the need to compete with other groups and the risk to lose a privileged social position conditioned the attempt of a liberal modernization among the nobles in the Austro-Hungarian compromise. In the second case is observed that after World War II, during early Stalinist regime, driven by a radical modernizing utopia and high levels of education, opportunities were created for previously discriminated social groups to enter public service, including state administration.

\section{KEYWORDS}

Elites. Reconversion. State. Hungary 